\title{
Playing Josephus on the English Stage
}

\author{
Peter Auger ${ }^{1}$
}

Published online: 16 August 2016

(C) The Author(s) 2016. This article is published with open access at Springerlink.com

Josephus's works were an ideal source for seventeenth-century English tragedy. Jacobean playwrights sought foreign settings for political drama at a time when censorship was heightened and national chronicle history had been exhausted of potential subject matter. The Jewish War and Antiquities offered fresh opportunities for biblical dramas of the kind that had been popular in the 1590 s but did not require the same creative restraint that scriptural adaptations did. ${ }^{1}$ Josephus was already popular in the vernacular: Thomas Lodge's version (first printed 1602) was the most frequently reprinted English translation of an ancient historian in early modern England; in addition, Peter Morwen's abridged translation of the Josippon had been reprinted thirteen times between 1558 and 1615 and was, like Lodge's translation, recommended to congregations from the pulpit. $^{2}$

Three surviving seventeenth-century English tragedies name Josephus as their main source: Elizabeth Cary's Tragedy of Mariam (composed c. 1604, printed 1613), Gervase Markham and William Sampson's Herod and Antipater (composed

\footnotetext{
1 M. Roston, Biblical Drama in England, London, 1968, p. 118; A. Connolly, 'Peele's David and Bethsabe: Reconsidering Biblical Drama of the Long 1590s', Early Modern Literary Studies, 16, 2007, 9.1-20 [http://purl.oclc.org/emls/si-16/connpeel.htm] (all weblinks accessed August 2015).

2 B. Groves, "“They repented at the preachyng of Ionas: and beholde, a greater then Ionas is here": $A$ Looking Glass for London and England, Hosea and the destruction of Jerusalem', in Early Modern Drama and the Bible: Context and Readings, 1570-1625, ed. A. Streete, Basingstoke, 2012, pp. 139-55 (146); R. Sowerby, 'Ancient History', in The Oxford History of Literary Translation in English, II: 1550-1660, ed. G. Braden, R. Cummings and S. Gillespie, Oxford, 2010, pp. 301-11 (302); P. Burke, 'A Survey of the Popularity of Ancient Historians, 1450-1700', History and Theory, 5, 1966, pp. 135-52 (152).
}

Peter Auger

p.auger@qmul.ac.uk

1 Queen Mary University of London, London, UK 
c. 1613, printed 1622) and William Heminge's The Jewes Tragedy (composed c. 1626, printed 1662). ${ }^{3}$ The lost play Titus and Vespasian (1592), mentioned in Henslowe's Diary, must have also drawn on Josephus. ${ }^{4}$ Today the best known of the three plays we have is Cary's closet drama, which is one of the earliest original plays written by an English woman. Alison Shell has written about Cary's use of Lodge's translation, such that the play claims to be a 'lexicon of moral exemplars' and its force 'derives in large part from her use of history as a means of merciless self-interrogation', particularly of the tensions and dilemmas of interpersonal relationships. ${ }^{5}$ Despite its suitability for stage performance, The Tragedy of Mariam may well have only been read aloud in a domestic aristocratic setting, which is exactly the sort of highly literate environment within which Josephus's works were best known in England at this time. ${ }^{6}$

The other two plays, however, reached a broader mix of audiences and readers of differing social status and educational backgrounds, and can therefore help us estimate how widely Josephus was known as a Jewish historian in early seventeenth-century England. Were Josephus's name and works, as well as being recognizable to scholars and aristocratic women, also known to readers of printed plays and even to popular playhouse audiences? The supposedly greater intellectual refinement of readers of plays compared to auditors was sometimes remarked on in contemporary prefaces to printed play texts: John Webster, for instance, complains to the reader in the preface to The White Devil (first performed 1612, printed 1631) by passing judgement on the play's first audiences at the Red Bull theatre who caused its commercial failure: 'most of the people that come to the playhouse resemble those ignorant asses (who visiting stationers' shops their use is not to inquire for good books, but new books). ${ }^{7}$ This note argues that we can detect the same difference in expectations between reader and spectator operating within the printed texts of both Markham and Sampson's and Heminge's plays, specifically in the inclusion of Josephus as a dramatic character: as chorus figure in Herod and Antipater, and as protagonist in The Jewes Tragedy. Although the speech prefixes in the early print editions indicate to a reader that an actor was playing the historian Josephus, who is also named on both plays' title-pages, an audience of either play would have struggled to make the connection between the character and the Jewish historian. 'Josephus' was apparently well known enough to advertise on the titlepages of printed plays and incorporate as a character, but was less likely to be known to the broader constituency of playgoers, which is why his character is not pinned to the historian in the performed play. From the evidence of these plays,

\footnotetext{
3 STC 4613 and 17402, and Wing H1425.

4 See the Lost Plays Database [http://www.lostplays.org/index.php/Titus_and_Vespasian]; I am grateful to the journal's anonymous reader for this reference.

5 A. Shell, 'Elizabeth Cary's Historical Conscience: The Tragedy of Mariam and Thomas Lodge's Josephus', in The Literary Career and Legacy of Elizabeth Cary, 1613-1680, ed. H. Wolfe, Basingstoke, 2007, pp. 53-67 (61-2, 60).

6 The Tragedy of Mariam, The Fair Queen of Jewry, ed. R. Wray, Arden Early Modern Drama, London, 2012, e.g. p. 63 .

7 The White Devil, ed. J. R. Brown, Manchester and New York, 1960; 1977, p. 30.
} 
Josephus's name seems to have been on the cusp of popular recognition in early modern England.

Markham and Sampson's Herod and Antipater is a crowd-pleasing throwback to earlier religious plays such as George Peele's David and Bethsabe (1592). Markham was a professional writer with a keen eye for popular trends who is best known today for his practical manuals on subjects such as horsemanship. A reference to a play Herodias indicates that his Tragedy of Herod and Antipater was written by 1613, but was subsequently revised with Sampson's help and printed in $1622 .{ }^{8}$ The title-page announces that the play is written 'according to IOSEPHVS, the learned and famous Iew', although in fact, as A. M. Silbermann and Gordon Nicholas Ross's scene-by-scene analyses show, the main source is actually Peter Morwen's History of the Latter Times of the Jewes Commune Weale (1558), a translation from a sixteenth-century Latin version of the Josippon that is six steps removed from Josephus's Greek. ${ }^{9}$ The play turns Herod and Antipater's story into a popular drama of passion, villainy and violence. Antipater's rise to power resembles Edmund's in King Lear: Antipater is even made a bastard son ('By birth I am a Bastard, yet my wit I Shall beare me 'boue the true borne', I.ii.33-4; B2r) though his historical mother was Herod's first wife, Doris. Antipater kills the High Priest Aristobulus and sets plots in train to have killed Mariam and her two sons, Princes Alexander and young Aristobulus. It is when Antipater turns his murderous intent against Herod that his true nature is finally revealed to the King. As Antipater is beheaded, Herod collapses from grief and dies too.

The character Josephus - distinguished in speech prefixes from Herod's brotherin-law Joseph who is also a character - introduces dumb shows in Acts II and IV that mime scenes from the historical narrative and direct a reader's or spectator's moral outlook on these stage events. In the first Josephus enters as a choral figure to point up a moral reading of Antipater's vanity and ambition:

Neuer grew Pride more high, more desperate;

Nor euer could the Arrogance of man

Finde out a Breast more large and spacious (II.i.630-31; F4r).

A dumb show follows which Josephus immediately summarizes:

The Sonnes of Marriam, hauing met the King [Herod],

Are ready for Encounter; but are staid

By th'awe of great Augustus (II.i.638-40).

\footnotetext{
8 D. Kathman, 'Sampson, William (b. 1599/1600, d. in or after 1655)', Oxford Dictionary of National Biography (ODNB) [http://www.oxforddnb.com/view/article/24596]; A Critical Edition of The True Tragedy of Herod and Antipater, Gervase Markham and William Sampson (1622), ed. G. N. Ross, Garland Publishing, New York and London, 1979, p. xii. All line references to Herod and Antipater are from this edition and are given in the body text.

9 Ibid., pp. vii-xii; A. M. Silbermann, Untersuchungen über die Quellen des Dramas The True Tragedy of Herod and Antipater, Wittenberg, 1927, Chapters 2 and 3.
} 
Two acts later, in the second dumb show, we see Augustus crown Antipater, who has schemes afoot against Alexander and young Aristobulus (Mariam is already dead) and against Herod too. Then Josephus enters:

Once more, I must intreat you to bestow

Much on Imagination; and to thinke,

That now our Bastard hath attain'd the top

And height of his Ambition

(IV.ii.276-9; I4v).

In introducing Josephus on-stage Markham and Sampson may well have been making another of the play's Shakespearean echoes, this one to Gower in Pericles, but with a significant dramaturgical difference in how the two literary choral figures are introduced. Shakespeare's Gower announces his identity within two lines of the prologue such that an audience immediately knows the identity of the speaker:

To sing a song that old was sung,

From ashes ancient Gower is come

(1 Chorus, 1-2).

Josephus, however, never announces his identity to the audience in the dialogue. Nor does he voice the prologue, which refers to Josephus in the third person, and may have been included in early performances only:

IOSEPHVS th'Ancient Writer, with a Pen

Lent by the Muses, giues new life to Men;

Who breath'd such Tragicke Accents forth to th'Eare

Of Hebrew Armies, which you now shall heare

(Pr. 7-9; A2v). ${ }^{10}$

While Gower introduces himself immediately and uses a first-person pronoun, the prologue to Herod and Antipater speaks of 'our play' in the first line, denoting the company, and through this quotation an audience is primed to hear Josephus's 'Tragicke Accents' but not necessarily Josephus speaking himself.

Readers of Markham and Sampson's text such as its dedicatee Sir Thomas Finch presumably knew of Josephus, even if they needed the reassurance that he was 'learned and famous'. Similarly, 'The Printers Epigrammatical Epistle, to the understanding Readers' presents this play as 'truely worth your reading, I Gather'd from learn'd Iosephvs' (11. 25-6) and assumes the reader's sense of cultural superiority:

\section{you contemne}

The drossy substance, highly priz'd by men

Of earthy breeding; who can never gleane

The least content from a true tragicke scoene

Of high and noble nature

(11. 8-10).

\footnotetext{
${ }^{10}$ T. Stern, “A Small-Beer Health to His Second Day”: Playwrights, Prologues, and First Performances in the Early Modern Theater', Studies in Philology, 101, 2004, pp. 172-99.
} 
These educated readers are more likely to have held and read a copy of Lodge's translation, which was already in its third edition by 1620 , and more likely to have drawn out the ethical marrow of that text. By contrast, when Herod and Antipater was performed at the Red Bull in 1621 to Webster's 'ignorant asses', an audience would have had no help from the script as printed a year later to identify the chorus as Josephus when he turns up in the middle of the play. ${ }^{11}$ The chorus serves the same dramaturgical purpose whether he is named or not. The inclusion of Josephus attests to a more 'literary' quality of the printed text, as promoted in its paratexts, that stressed the authenticity of the historical narrative. The play's readers would more readily have appreciated direct allusions to Josephus's name than an audience would.

An audience's contexts for interpretation were likely to have been more contemporary than classical, especially as the play can be read as an oblique reflection on recent political events. This application of the play's ideas to later history is another reason for Josephus's appeal as source, just as Shakespeare could think 'both historically and unhistorically at once' when adapting Plutarch. ${ }^{12}$ For example, Mariam's implication in the accusation made against Herod's cup-bearer Pheroas of poisoning possibly resonated with Francis Howard's role in Thomas Overbury's murder in 1613; as Ross writes (with some exaggeration), '[i]n broadest terms ... the Jacobean audiences should have been able to see in the play whatever they wanted to'. ${ }^{13}$ The references to Josephus in the printed text, reinstating the classical basis for the play, were partly a matter of elevating its status as a Jacobean drama for its readers once the relevance to current affairs had faded. In this reading, references to Josephus on the title-page and dedicatory material in Herod and Antipater reinforce the moral, historical and erudite qualities of the story being presented, and in effect create distance from audiences at the Red Bull, who probably were not made to imagine that Josephus had stepped onto the stage.

Similarly, the Josephus character in William Heminge's Jewes Tragedy, though very different from Markham and Sampson's, need not be connected with the historian either when performed on-stage. Heminge was certainly in London when Herod and Antipater was staged and printed, and may have sought to replicate its popular appeal; as Carol Morley, the play's editor, argues, 'the tone and stagecraft of both plays are at times strikingly similar'. ${ }^{14}$ The play's eponymous Jews are the three seditious captains Eleazer, Jehochanan and Simeon, who defect during Nero's and Vespatian's ( sic) assaults on Jerusalem; the central action of the play concerns their treachery, aided by the poor Jew Zareck, and downfall. The play was probably composed between about 1626 and 1630, was possibly performed at Heminge's college Christ Church at that time, and - given its gruesome additions, its prologues

\footnotetext{
${ }^{11}$ M. Steggle, 'Markham, Gervase (1568?-1637)', ODNB [http://www.oxforddnb.com/view/article/ 18065].

12 C. Burrow, Shakespeare and Classical Antiquity, Oxford, 2013, p. 205.

13 Ross, Herod and Antipater (n. 8 above), pp. xvi-xvii.

14 The Plays and Poems of William Heminge, ed. C. Morley, Madison and Teaneck, 2006, p. 75. All references to The Jewes Tragedy are from this edition and are given in the text.
} 
and epilogues - may well have been intended for public theatre, though we have no evidence that it was. ${ }^{15}$ It was printed only in 1662, perhaps timed for the proclamation officially welcoming Jews back to England, and also coinciding with the time when the bookseller Richard Gammon was selling Heminge's other play, The Fatal Contract.

The Jewes Tragedy also advertises prominently on its title-page that its narrative source is the 'Authentick and Famous History of Josephus'. Heminge is again most dependent on Morwen's account, taking Joseph Ben Gorion and Josephus to be one person. This is evident from the character list, which names one 'Joseph Son to Gorion and Captain of the Iews', and we find later sensationalizing incidents between father and son, including a scene in which Joseph watches the Romans torture his father. The part of Joseph is a substantial development from the source: he defects to the Romans early in the play and becomes the hero of the drama, the sane voice decrying the violence and concerned for Jerusalem's safety. In his opening speech, Josephus reflects with his father about the human propensity to grieve:

'Tis true; yet such is Nature that it strives to know

It self in wretchedness, how truly we

Acquire the center of our misery (I.iv.153-5).

By the play's conclusion, Titus has promoted Josephus to his deputy:

Tit. O My Josephus! how I grieve to see

the ruines of thy fair Jerusalem:

But as it is, I give the sacred power

to be dispos'd by thee.

Jos. Thanks, my most honoured Lord. (V.viii.9-13; K3r)

The hero's power consolidated, Josephus confirms to the audience the intended moral judgements of Skimeon and Jehochanan ('the cruel Skimeon; And this Jehochanan', V.viii.56-7), Miriam ('The wofull mother of a murther'd son', V.viii.105) and Zareck ('that cursed wretch that blew the coles I Of hot dissention 'twixt the Citizens', V.viii.163-4).

Again, Josephus's character holds the key to a moral reading of the play, and an educated reader familiar with Morwen's, Lodge's or other Josephan texts could easily realize that Heminge had creatively introduced the historian into the play's action. Markham and Sampson's Josephus may also have been an inspiration. Given that the play is chiefly known for its appropriative borrowings from Shakespearean tragedies - Eleazar, for example, sounds at different points like Hamlet ('To be, or not to be, I there's the doubt', III.ii.1; E1r), Lear, Macbeth and Antony - Josephus's emergence as a narrator acting as a witness for the play's events may be another Shakespearean motif, inspired perhaps by Edgar in King Lear or Hamlet's Horatio. Whatever the intertextual connections operating in The Jewes Tragedy that led to the creation of Josephus's character, the play's potential audience still has no reason to connect the character Joseph with the historian Josephus: the script contains no

15 Ibid., p. 42. 
internal clues or hints that Joseph will emerge as the narrator of these events. If the play was ever performed beyond the university setting, then Heminge's adaptation of Josephus as a character would not have been obvious.

In the two plays considered in this paper, Josephus's identity was not relevant to staging an effective drama which used a version of Josephus as a source. The prominent inclusion of Josephus's name on the plays' title-page would have elevated their status by bolstering their authenticity and moral value. Readers were expected to come to Markham and Sampson's or Heminge's play for fresh, original and morally upstanding adaptations of Josephus; immersing the author of the source in the action was a novel way, possibly following various Shakespearean precedents, to enliven the re-telling as well as upholding its factual authority. But these additions are separate to how the plays functioned as performed texts, and probably did not translate to performance practice. So while these and other adaptations in early modern Europe demonstrate respect for Josephus as a historical figure and even created opportunities for him to appear as a character on-stage, a popular audience did not need to recognize his name, and probably could not have done so.

Open Access This article is distributed under the terms of the Creative Commons Attribution 4.0 International License (http://creativecommons.org/licenses/by/4.0/), which permits unrestricted use, distribution, and reproduction in any medium, provided you give appropriate credit to the original author(s) and the source, provide a link to the Creative Commons license, and indicate if changes were made. 